\title{
Educational Status of Yanadi Tribe Children in Early Childhood (3-8 Years)
}

\author{
B. Vijayasree* and D. Sarada \\ Human Development and Family Studies, Department of Home Science, Sri Padmavati \\ Mahila Visvavidyalayam, Tirupati - 517502, Andhra Pradesh, India \\ *Corresponding author
}

\begin{tabular}{|c|}
\hline \\
\hline $\begin{array}{l}\text { Early child hood, Yanadi } \\
\text { children, Educational } \\
\text { status, Reasons for not } \\
\text { attending school } \\
\text { /Anganwadi }\end{array}$ \\
\hline Article Info \\
\hline $\begin{array}{l}\text { Accepted: } \\
10 \text { October } 2018 \\
\text { Available Online: } \\
10 \text { November } 2018\end{array}$ \\
\hline
\end{tabular}

\section{A B S T R A C T}

The present study is taken up to assess the Educational status of Yanadi tribe children aged between 3-8 years. Sample size comprises of 250 children in the age group of 3-8 years. The tools like standardised questionnaire, Focus group discussions and services and opportunities mapping was used for collecting qualitative data from the parents of the sample. The study results revealed that in the age group of Pre-school only 13 percent of sample were attending the Anganwadi. Enrolled but not attending were found to be 21.6 percent, while 12.5 percent of them have not enrolled. Very less percentage that is 9 percent were attending primary school, while 24.5 percent absenting from school frequently and 19 percent of children were not enrolled and are out of school children. Regarding the reasons of not attending school; the findings revealed that educational services were not utilized by majority of the tribal children, the reasons stated by the parents in Focus Group Discussions were; Anganwadi and Primary School are far away, difficult to get the children prepare and send to school without an adult to accompany, poverty, need children to help in work, cannot help in school work, children fear punishments in school.

\section{Introduction}

Early childhood is a stage of rapid development in all the domains of physical, mental, language, social and emotional. Realizing the great importance of this stage both as a feeder and a strengthening factor for primary education and human resource development in general, the National policies and programs emphasized the need for all round development of the child. Early childhood is regarded as foundation stage for later stages of development. Thus early childhood is very significant and important stage in human development and is marked with rapid cognitive development (Shukla, 2008).

The education is one of the pre requisites for development of tribals and non tribals. For promotion of education, in addition to introduction of schools at various levels, several schemes have been worked out to give a boost to education among tribal children. Some of the key schemes have been residential schools, vocational education, 
scholarships, book grants, free uniforms, midday meals, etc. (Virginius Xaxa) The low attendance and high drop-out rates among tribal children has been attributed to poor curriculum and syllabus, deficient pedagogy and negligent teachers and poor infrastructural facilities especially for girls lack of toilet facilities.In addition parents are also accountable for school drop-out rate $s$ and poor enrolment of tribal children in schools (Dubey 2009).

Malyadri and Pacha (2011) conducted a study which analyzed the problems in the field of Tribal children education and suggest measures for the development of education among the Tribals in Khammam District of Andhra Pradesh state in India. The study revealed that People of the remote area are superstitious and addicted to blind beliefs. Hence, they do not understand the value of education. The survey conducted in Khammam districts Andhra Pradesh showed that only 15 percent to 40 percent tribal children attend the school (Hanumantha, 2006). This study identified explored reasons for the drop out problem which include the medium of teaching such as; Telugu language is a foreign language for the tribal children. The preconceived notions of the teachers that the tribal children cannot grasp anything beyond nature, forest and agriculture create barriers in expanding primary education among the tribal areas. Children's engagement in household works agriculture coupled with parent's indifference towards their children's studies deprive the teachers to render their services in the classroom.

Chattopadhyaya and Durdhawale (2009) focuses on the situation of primary school attendance of tribal children in some selected villages of Nandurbar district. The main objectives of the study are: to assess the situation of non-attendance of schools among tribal children aged $6-12$ as reported by their parents and the reasons behind such nonattendance and to understand the quality of schools of the selected villages. The study also examines the gender difference in schooling. The sample constituted parents (father or mother) of tribal children in the age range 6 12 selected from the households of Khadki and Toranmal villages of Nandurbar district, Maharashtra. The total number of households selected was 183 and total number of children (6 - 12 years age) residing in that 183 households were 245 . The study utilized both primary and secondary data collected by using both qualitative and quantitative tools. Besides infrastructural improvements, the study strongly favors introduction of tribal languages for basic education, provision of personnel for clerical works and proper maintenance of records that reflects the reality of primary schooling. Economic uncertainty and financial hardship are the contributing factors for the age-old disinterest in education among the tribes. Thus increasing the sources of income is the only way to encourage willing participation in basic education.

Rajam and Malarvizhi (2011) conducted a survey on in Indian context, was: (a) studied the formal level of education and achievement among the Tribal group; (b) studied the parental objective in educating the children; (c) found the reasons for taking education; (d) found the knowledge about the reservation of seats for Scheduled Caste and financial aid for children; and (e) assessed the difficulties faced by them. The study made use of sample of 600 girls in the Nilgris selected by adopting purposive random sampling technique. The study concluded that though the educational opportunities are adequate in Nilgris, the given opportunities for education were not utilized fully; sometimes they were opposed by their own caste people, which resulted in conflicts, problems and tensions. The study suggested that, Massive community programme could be taken with a view to 
change the aspiration levels of the disadvantaged children and a crèche attached to the school may lighten the domestic burden of school girls.

Sarva Shiksha Abhiyan (2008), Hyderabad conducted a study on tribal education with different types of objectives. The programme is implemented in 10 selected schools in each of the 8 tribal dialects in 8 ITDAs from the academic year 2004-05 with various major objectives. Multilingual education: During 2005-06 class-II textbooks and 2006-07 classIII textbooks are developed and implemented in selected tribal schools.

The implications were a total of 238 children in the age group of 5-15 years have been identified through a 'boat to boat' survey; among them 92 children was enrolled into on boat, local elementary schools, Residential Bridge Course Campus, etc. and Alternative schooling at Brick-Kilns. From CLIP and CLAPS programmes identified that the objectives are reached up to $80 \%$.

The main objectives of this study includes, to assess the Educational status of Yanadi tribe children in Early Childhood (3-8 years).

\section{Materials and Methods}

\section{Sampling procedure}

Sample size comprises of 250 children who fulfil the inclusive criteria. Selection of 12 tribal (Yanadi) habitations from four mandals of Guntur district (Chebrolu, Ponnur, Kakumanu \& Amarthaluru). Selection The sample selected from the population frame consisted of 250 children of which 69 were boys and 60 girls aged between 3-5 years and 70 were boys and 61 were girls aged between 6-8 years of Yanadi children between 3-8 years.

\section{Tools and techniques used}

The questionnaire developed by Sarada (2013) was adopted and standardised for the study. The information on Educational status of the children was collected. That is whether the children enrolled in Anganwadi / Preschool / Primary school and attending the school.

\section{Focus group discussion}

Focused group discussions were carried out to explore their awareness on different domains of Education of tribal children and their parents for in depth understanding. The parents of the sample formed into groups in all the twelve habitations under study.

The researcher facilitated discussion on the availability, regularity and utilisation of Educational services for their children. This Focus Group Discussion was recorded for qualitative analysis.

\section{Services and opportunities mapping}

Services and Opportunities map is one of the PRA method used to explore the spatial realities of the local people with specific reference to the local people's perceptions of the services and opportunities available.

The focus is on the availability of services and opportunities while in the later the focus is on the places local people visit.

A services and opportunities map in addition can also be reflect the distance, importance and accessibility of local services as perceived by the participants.

\section{Results and Discussion}

The educational status of tribal children aged between 3 to 8 years was assessed and presented in the table 1 . 
The table 1 depicts the educational status of the respondents. The study findings reveal that only 13 percent of samples were attending the Anganwadi.

Enrolled but not attending were found to be 21.6 percent, while 12.5 percent of them have not enrolled. Very less percentage that is 9 percent were attending primary school, while 24.5 percent absenting from school frequently and 19 percent of children were not enrolled and are out of school children. Hence the null hypothesis $\left(\mathrm{H}_{0} 5\right)$ " the educational status of Yanadi tribe children is poor was accepted" (Fig. 1 and 2).

Table.1 Educational status of the sample

\begin{tabular}{|l|}
\hline Status \\
\hline Going to Anganwadi \\
\hline Enrolled but not attending \\
\hline Not enrolled in Anganwadi \\
\hline Attending Primary school \\
\hline Absenting from school \\
\hline Not enrolled in Primary school \\
\hline
\end{tabular}

Frequency

\begin{tabular}{|c|c|}
\hline 16 & 13 \\
\hline 26 & 21.6 \\
\hline 15 & 12.5 \\
\hline 11 & 9 \\
\hline 29 & 24.5 \\
\hline
\end{tabular}

Table.2 Reasons for not attending the school

\begin{tabular}{|l|c|c|}
\hline Reasons & Frequency & Percentage (\%) \\
\hline Marginalized & 30 & 25 \\
\hline Not interested & 18 & 15 \\
\hline Long distance & 15 & 12.50 \\
\hline Lack of proper amenities & 5 & 4 \\
\hline IIllness & 52 & 43.30 \\
\hline
\end{tabular}

Fig.1 Educational status of the respondents

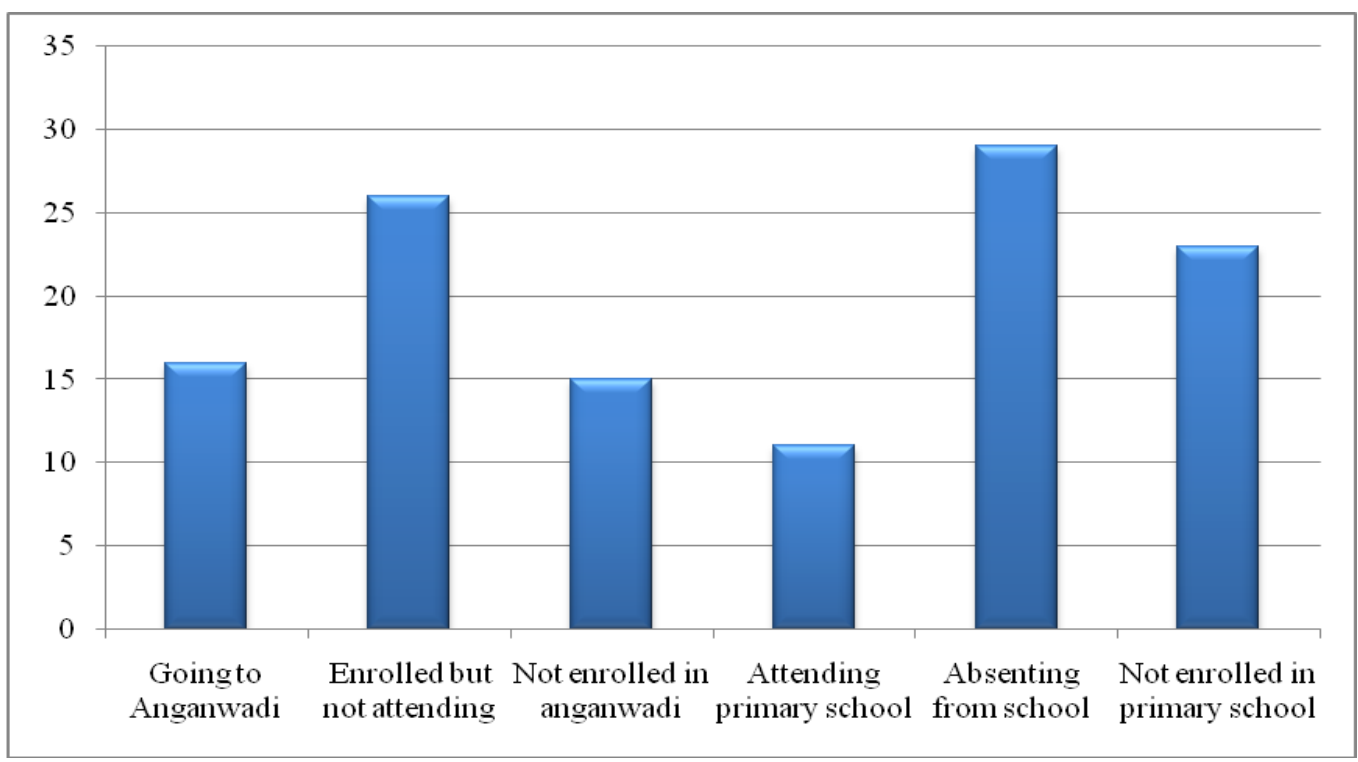


Fig.2 Reasons for not attending School/Anganwadi



The table 2 provides the reasons of not attending school; the findings reveal that 25 percent are not attending as they get marginalized in their school. It is noted that 15 percent of the respondents don't attend school as they are not interested. The reason for not attending was long distance $(12.5 \%)$, lack of proper amenities (4\%) and major reason by majority of respondents $(43.3 \%)$ was illness. This shows that the educational services were not utilized by majority of the tribal children, the reasons stated by the parents in Focus Group Discussions were; Anganwadi and school are far away, difficult to get the children prepare and send to school without an adult to accompany, poverty, need children to help in work, cannot help in school work, children fear punishments in school.

The study results revealed that in the age group of Pre-school only 13 percent of sample were attending the Anganwadi. Enrolled but not attending were found to be 21.6 percent, while 12.5 percent of them have not enrolled. Very less percentage that is 9 percent were attending primary school, while 24.5 percent absenting from school frequently and 19 percent of children were not enrolled and are out of school children. Regarding the reasons of not attending school; the findings revealed that educational services were not utilized by majority of the tribal children, the reasons stated by the parents in Focus Group Discussions were; Anganwadi and Primary School are far away, difficult to get the children prepare and send to school without an adult to accompany, poverty, need children to help in work, cannot help in school work, children fear punishments in school. The preschool education being implemented through ICDS programs are availed by the tribal families to a small extent due to problems in accessibility. The Pre-school and primary school education programmes are not much utilized by tribal population as they are located in the heart of the main villages. The social discrimination and poverty dissuades the tribal families from sending their children to schools. This can be overcome by educating tribal families on the benefits of education. 


\section{References}

Chattopadhyaya and Durdhawale (2009). Journal of Education Administration and Policy Studies Vol.1 (5), pp. 070078, September, Academic Journals, children of Bihar." Indian Pediatrics, 36: 37-42.

Dubey, Muchkund, 2010. The Right of Children to Free and Compulsory Education Act: 2009: The Story of a Missed Opportunity, Social Change, 40(1) pp.-1-13)

Hanumantha, Samby Reddy, 2006. Education for tribal children: An engine for human development International Journal of Research Studies in Education 2012 January, Volume 1 Number 1, 99-106

Malyadri and Pacha, (2011). The problems in the field of Tribal children education and suggest measures for the development of education among the Tribals in Khammam District of Andhra Pradesh state in India

Rajam and Malarvizhi, (2011). Educational status of tribal children in the Nilgiris district.

Sarva Shiksha Abhiyan (2008). Hyderabad A Study on tribal education with different types of objectives

Shukla. R.P. (2008) Early Childhood Care and Education, Published by Sarup and Sons, New Delhi, ISBN: 81-7625-4746.

Virginiusxaxa (2011). The Statue of Tribal children in India: A Historical Perspective IHD-UNICEF working paper series, children of India: rights and opportunities, working Paper No7.

\section{How to cite this article:}

Vijayasree, B. and Sarada, D. 2018. Educational Status of Yanadi Tribe Children in Early Childhood (3-8 Years). Int.J.Curr.Microbiol.App.Sci. 7(11): 877-882. doi: https://doi.org/10.20546/ijcmas.2018.711.104 